\title{
BMJ Open Geographical prevalence and risk factors for pterygium: a systematic review and meta-analysis
}

\author{
Lei Liu, ${ }^{1,2}$ Jingyang Wu, ${ }^{1}$ Jin Geng, ${ }^{1}$ Zhe Yuan, ${ }^{1}$ Desheng Huang ${ }^{2,3}$
}

To cite: Liu L, Wu J, Geng J, et al. Geographical prevalence and risk factors for pterygium: a systematic review and meta-analysis. BMJ Open 2013;3:e003787. doi:10.1136/bmjopen-2013003787

- Prepublication history for this paper is available online. To view these files please visit the journal online (http://dx.doi.org/10.1136/ bmjopen-2013-003787).

Received 13 August 2013 Revised 9 October 2013 Accepted 10 October 2013

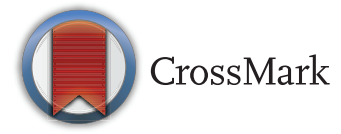

For numbered affiliations see end of article.

Correspondence to Professor Desheng Huang; haungdsI|@163.com

\section{ABSTRACT}

Objective: Pterygium is considered to be a proliferative overgrowth of bulbar conjunctiva that can induce significant astigmatism and cause visual impairment; this is the first meta-analysis to investigate the pooled prevalence and risk factors for pterygium in the global world.

Design: A systematic review and meta-analysis of population-based studies.

Setting: International.

Participants: A total of 20 studies with 900545 samples were included.

Primary outcome measure: The pooled prevalence and risk factors for pterygium.

Results: 20 studies were included. The pooled prevalence of pterygium was $10.2 \%(95 \% \mathrm{Cl} 6.3 \%$ to $16.1 \%)$. The pooled prevalence among men was higher than that among women (14.5\% vs $13.6 \%$ ). The proportion of participants with unilateral cases of pterygium was higher than that of participants with bilateral cases of pterygium. We found a trend that the higher pooled prevalence of pterygium was associated with increasing geographical latitude and age in the world. The pooled OR was 2.32 (95\% $\mathrm{Cl} 1.66$ to 3.23$)$ for the male gender and $1.76(95 \% \mathrm{Cl} 1.55$ to 2.00$)$ for outdoor activity, respectively.

Conclusions: The pooled prevalence of pterygium was relatively high, especially for low latitude regions and the elderly. There were many modifiable risk factors associated with pterygium to which healthcare providers should pay more attention.

\section{INTRODUCTION}

Pterygium is a common fibrovascular proliferative disease affecting the ocular surface; it can result in ocular irritation, visual disturbances and so on. ${ }^{1}$ Many previous reports have shown the prevalence of, and risk factors for, pterygium in population-based studies, but the prevalence of pterygium varies widely with geography, age and gender in different samples, ${ }^{2}$ and the data remain limited and localised. Although the exact aetiology of pterygium is unknown, there seems to be an association between outdoor

\section{Strengths and limitations of this study}

- We estimated the pooled prevalence data using meta-analysis, rather than the prevalence in a single national population-based study.

- We only included studies written in English or Chinese and published from January 2000 to May 2013, so the pooled prevalence of pterygium in specific regions and periods is explained by the results.

- As we cannot have access to unpublished results, a publication bias cannot be excluded.

- The pooled analysis of some other risk factors was not produced due to insufficient data.

work and pterygium formation, ${ }^{3}$ especially with ultraviolet (UV) radiation. Increasing geographical latitude was associated with a reduced pterygium OR. ${ }^{4}$ Until now, there is no national, population-based study on the prevalence of pterygium in the world, and it would seem that a national, pooled estimate based on the global population is necessary. In this meta-analysis, we carried out a systematic review of previous population-based studies on the prevalence of, and risk factors for, pterygium in the world and investigated any differences among age groups, genders and geographical latitude.

\section{METHODS}

\section{Search strategy}

We searched all English reports on populationbased studies for the prevalence of, and risk factors for, pterygium using MEDLINE, EMBASE, Web of Science and Google (scholar), and all Chinese reports were searched manually and online using the Chinese Biochemical Literature on Disc (CBMDisc), Chongqing VIP database and China National Knowledge Infrastructure (CNKI) database. The search keywords were: pterygium, pterygia, prevalence, epidemiology and risk factor. Reference lists were checked and researchers contacted for additional 
literature. A total of 138 reports published in the period from January 2000 to May 2013 were identified.

\section{Inclusion and exclusion criteria}

The review and analysis were conducted using the Preferred Reporting Items for Systematic Reviews and Meta-analyses (PRISMA) Statement as a guide. ${ }^{5}$ Reports potentially eligible for inclusion in this systematic review and meta-analysis had to meet the following criteria: they had to be population-based studies, original, written in English or Chinese, and needed to provide sufficient information to estimate the pooled prevalence of, and risk factors for, pterygium. If more than one study was based on the same population sample, the study of the highest quality was included. We excluded studies that were on the duplicate population groups but were of lower quality, whose participants were drawn from a particular occupation or population, and that did not satisfy one or more inclusion criteria.

A total of 138 potentially relevant studies were identified and screened. After systematic review, only 20 of these were included in the meta-analysis. The progress for study inclusion is shown in figure 1 .

\section{Data extraction}

Two researchers (LL and JG) independently searched the literature. Data were extracted from each article using a standardised form including first author, publication year and $e t a l$. The characteristics of the populationbased studies included in this meta-analysis on the pooled prevalence of pterygium in the world are shown in table 1.

We systematically assessed several key points of study quality proposed by the MOOSE Collaboration ${ }^{25}$ The quality of the included studies is shown in table 2.

\section{Data analysis}

OR was analysed using the RevMan V.5.0 (Review Manager, Copenhagen: the Nordic Cochrane Centre, the Cochrane Collaboration, 2010) statistical software package. Meta-analyst statistical software offered by http://tuftscaes.org/meta_analyst/ was used to analyse

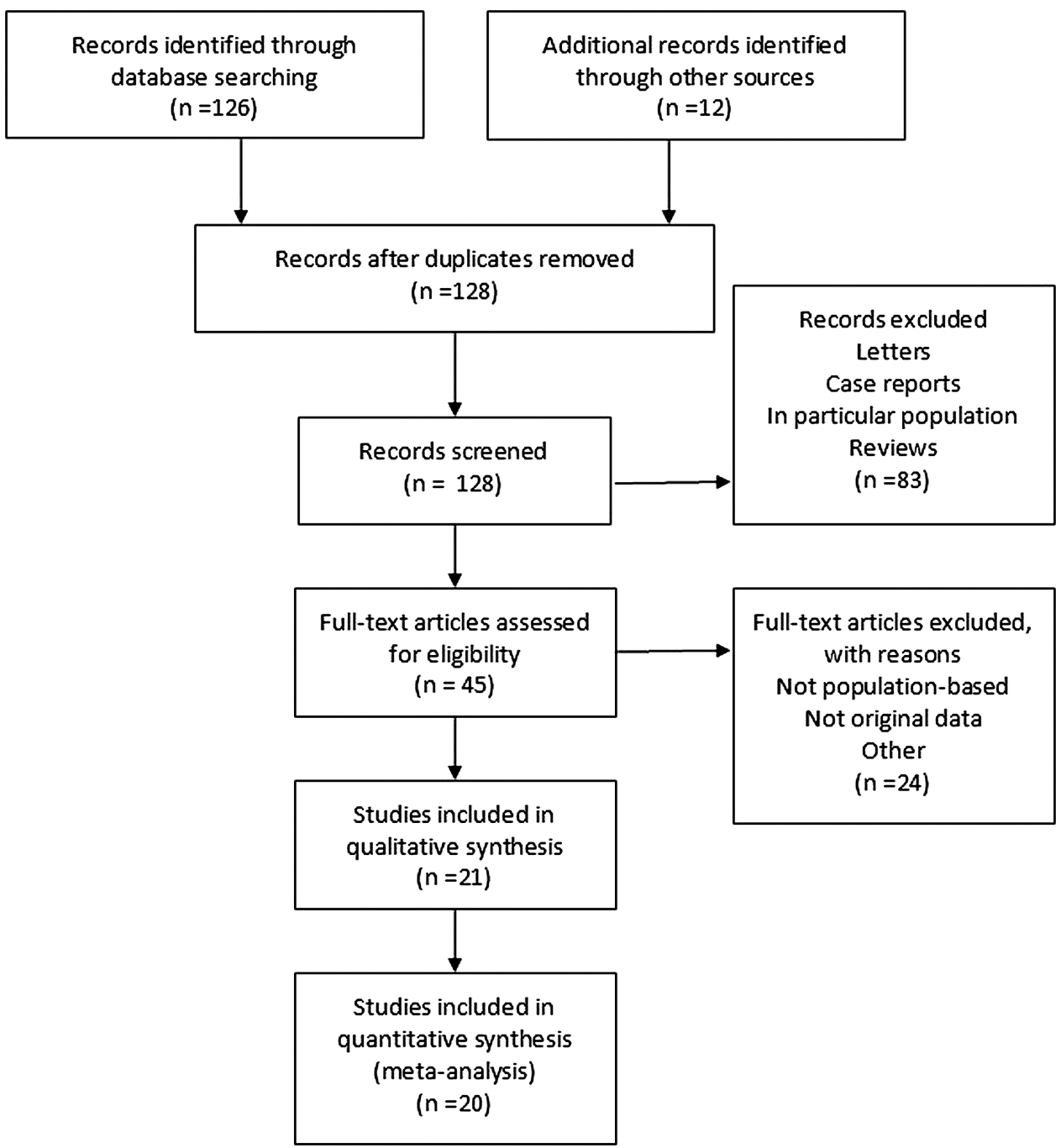

Figure 1 Flow chart demonstrating those studies that were processed for inclusion in the meta-analysis. 
Table 1 Characteristics of population-based studies on the prevalence of pterygium

\begin{tabular}{|c|c|c|c|c|c|c|c|c|c|c|c|}
\hline No. & First author & $\begin{array}{l}\text { Publication } \\
\text { year }\end{array}$ & Country & Regional & Area & Ethnic & $\begin{array}{l}\text { Rural/ } \\
\text { urban }\end{array}$ & $\begin{array}{l}\text { Survey } \\
\text { year }\end{array}$ & $\begin{array}{l}\text { Age range } \\
\text { (years) }\end{array}$ & $\begin{array}{l}\text { Sample } \\
\text { size }(n)\end{array}$ & $\begin{array}{l}\text { Cases } \\
\text { (n) }\end{array}$ \\
\hline 1 & $\begin{array}{l}\text { Cajucom-Uy } \\
\text { et } a^{f}\end{array}$ & 2010 & Singapore & $\begin{array}{l}1^{\circ} 09^{\prime}-1^{\circ} 29 \mathrm{~N}, 103^{\circ} \\
38^{\prime}-104^{\circ} 6^{\prime} \mathrm{E}\end{array}$ & $\begin{array}{l}\text { South-western part of } \\
\text { Singapore }\end{array}$ & Malay & NA & $2004-2006$ & $40-79$ & 3280 & 508 \\
\hline 2 & Wu et al & 2002 & China & $\begin{array}{l}22^{\circ} 12^{\prime \prime} \mathrm{N}, 113^{\circ} \\
15^{\prime \prime} \mathrm{E}\end{array}$ & Doumen County & Chinese & Rural & 1997 & $\begin{array}{l}50 \text { years or } \\
\text { over }\end{array}$ & 4214 & 1391 \\
\hline 3 & Paula et $a{ }^{\beta}$ & 2006 & Brazil & $0^{\circ} 9^{\prime} \mathrm{S}, 68^{\circ} 54^{\prime} \mathrm{W}$ & $\begin{array}{l}\text { Sao Gabriel da } \\
\text { Cachoeira City }\end{array}$ & Indian & Rural & 1997-1999 & NA & 624 & 115 \\
\hline 4 & Viso et a ${ }^{\rho}$ & 2011 & Spain & $42^{\circ} \mathrm{N}$ & O Salnes & Spanish & Urban & 2005-2006 & $40-96$ & 619 & 42 \\
\hline 5 & Fotouhi et al ${ }^{10}$ & 2009 & Iran & $35^{\circ} \mathrm{N}, 50^{\circ} \mathrm{E}$ & Tehran & Persian & Urban & 2002 & All age & 4564 & 66 \\
\hline 6 & Durkin et al ${ }^{11}$ & 2008 & Myanmar & $20^{\circ} 53^{\prime} \mathrm{N}, 95^{\circ} 53^{\prime} \mathrm{E}$ & Meiktita & Burmese & Rural & 2005 & $\begin{array}{l}40 \text { years } \\
\text { and over }\end{array}$ & 2076 & NA \\
\hline 7 & Wong et $a l^{12}$ & 2001 & Singapore & $1^{\circ} 16^{\prime} \mathrm{N}, 103^{\circ} 51^{\prime} \mathrm{E}$ & Tanjong Pagar & Chinese & NA & 1997-1998 & $40-79$ & 1232 & 120 \\
\hline 8 & Lu et $a l^{13}$ & 2009 & China & $\begin{array}{l}34^{\circ} 4^{\prime}-55^{\prime} \mathrm{N}, 100^{\circ} \\
53^{\prime}-102^{\circ} 15^{\prime} \mathrm{E}\end{array}$ & Henan County & Mongolian & Rural & 2006 & $\begin{array}{l}40 \text { years } \\
\text { and over }\end{array}$ & 2112 & 378 \\
\hline 9 & Tan et $a l^{14}$ & 2006 & Indonesia & $1^{\circ} 53^{\prime} \mathrm{N}, 101^{\circ} 44^{\prime} \mathrm{E}$ & Pulau Jaloh & Indonesia & NA & NA & All age & 477 & 81 \\
\hline 10 & Liang et $a l^{15}$ & 2010 & China & $39.6^{\circ}-40.3^{\circ} \mathrm{N}$ & Beijing & Chinese & Rural & 2008-2009 & $55-85$ & 37067 & 1395 \\
\hline 11 & $\begin{array}{l}\text { Bueno-Gimeno } \\
\text { et } a l^{16}\end{array}$ & 2002 & Algeria & $27^{\circ} 42^{\prime} \mathrm{N}, 8^{\circ} 10^{\prime} \mathrm{W}$ & Tindouf & Saharan & NA & 1997 & $6-80$ & 1322 & 138 \\
\hline 12 & Luthra et $a 1^{17}$ & 2001 & Barbados & $13^{\circ} 11^{\prime} \mathrm{N}, 60^{\circ} 27^{\prime} \mathrm{W}$ & Barbados & Barbadian & Urban & NA & $40-84$ & 2781 & 613 \\
\hline 13 & McCarty et al ${ }^{18}$ & 2000 & Australia & $38^{\circ} 53^{\prime} \mathrm{S}, 144^{\circ} 45^{\prime} \mathrm{E}$ & Victoria & Victorians & $\begin{array}{l}\text { Rural/ } \\
\text { urban }\end{array}$ & & $\begin{array}{l}40 \text { years } \\
\text { and over }\end{array}$ & 5147 & 142 \\
\hline 14 & Shiroma et $a l^{19}$ & 2009 & Japan & $26^{\circ} 20^{\prime} \mathrm{N}, 126^{\circ} 48^{\prime} \mathrm{E}$ & Kumejima & Japanese & NA & 2005-2006 & $\begin{array}{l}40 \text { years } \\
\text { and over }\end{array}$ & 3747 & 1154 \\
\hline 15 & Ma et $a{ }^{20}$ & 2007 & China & $39^{\circ} 54^{\prime} \mathrm{N}, 116^{\circ} 23^{\prime} \mathrm{E}$ & Beijing & Chinese & $\begin{array}{l}\text { Rural/ } \\
\text { urban }\end{array}$ & 2001 & $\begin{array}{l}40 \text { years } \\
\text { and over }\end{array}$ & 4439 & 128 \\
\hline 16 & $\begin{array}{l}\text { West and } \\
\text { Muñoz }^{21}\end{array}$ & 2009 & USA & $\begin{array}{l}31^{\circ}-32^{\circ} \mathrm{N}, 111^{\circ} \\
3^{\prime}-4^{\prime} \mathrm{W}\end{array}$ & Nogales and Tucson & Hispanic & NA & NA & $\begin{array}{l}40 \text { years } \\
\text { and over }\end{array}$ & 4774 & NA \\
\hline 17 & Liu et $a P^{2}$ & 2001 & China & $\begin{array}{l}18^{\circ}-19^{\circ} \\
N, 108^{\circ}-109^{\circ} \mathrm{E}\end{array}$ & Hainan & Chinese & Rural & 1999 & $12-88$ & 7990 & 628 \\
\hline 18 & Gazzard et $a^{P^{3}}$ & 2002 & Indonesia & $1^{\circ} \mathrm{N}$ & Riau province & $\begin{array}{l}\text { Malay/ } \\
\text { Indonesians }\end{array}$ & Rural & 2001 & $\begin{array}{l}21 \text { years } \\
\text { and over }\end{array}$ & 1210 & NA \\
\hline 19 & Sherwin et $a P^{4}$ & 2013 & Australia & $29^{\circ} 2^{\prime} \mathrm{S}, 167^{\circ} 56^{\prime} \mathrm{E}$ & & NA & NA & 2007 & $\begin{array}{l}15 \text { years } \\
\text { and over }\end{array}$ & 641 & 70 \\
\hline 20 & Lu et aP & 2007 & China & $35^{\circ} 2^{\prime} \mathrm{N}, 101^{\circ} 5^{\prime} \mathrm{E}$ & Zeku & Tibetan & $\begin{array}{l}\text { Rural/ } \\
\text { urban }\end{array}$ & 2006 & $\begin{array}{l}40 \text { years } \\
\text { and over }\end{array}$ & 2229 & 323 \\
\hline
\end{tabular}

E, east latitude; N, north latitude; NA, not available; S, south latitude; W, west latitude. 
Table 2 Quality for the population-based studies on the prevalence of pterygium

\begin{tabular}{|c|c|c|c|c|c|c|c|c|}
\hline No. & First author & $\begin{array}{l}\text { Publication } \\
\text { year }\end{array}$ & $\begin{array}{l}\text { Sampling } \\
\text { scheme }\end{array}$ & $\begin{array}{l}\text { Population } \\
\text { characteristics }\end{array}$ & $\begin{array}{l}\text { Prevalence } \\
\text { definition }\end{array}$ & $\begin{array}{l}\text { Diagnostic } \\
\text { criteria }\end{array}$ & $\begin{array}{l}\text { Response } \\
\text { rate }\end{array}$ & $\begin{array}{l}\text { Total } \\
\text { score }\end{array}$ \\
\hline 1 & $\begin{array}{l}\text { Cajucom-Uy } \\
\text { et } a^{\beta}\end{array}$ & 2010 & Yes & Yes & Yes & Yes & $0.787 \%$ & 5 \\
\hline 2 & Wu et $a l^{7}$ & 2002 & Yes & Yes & Yes & Yes & $88.49 \%$ & 5 \\
\hline 3 & Paula et $a^{\beta}$ & 2006 & NA & Yes & NA & Yes & NA & 2 \\
\hline 4 & Viso et $a^{\rho}$ & 2011 & Yes & Yes & Yes & Yes & $66.10 \%$ & 5 \\
\hline 5 & Fotouhi et al ${ }^{10}$ & 2009 & Yes & Yes & Yes & Yes & $70.30 \%$ & 5 \\
\hline 6 & Durkin et $a l^{11}$ & 2008 & Yes & Yes & Yes & Yes & $83.70 \%$ & 5 \\
\hline 7 & Wong et $a l^{12}$ & 2001 & Yes & Yes & Yes & Yes & $71.80 \%$ & 5 \\
\hline 8 & Lu et $a l^{13}$ & 2009 & Yes & Yes & Yes & Yes & $84.90 \%$ & 5 \\
\hline 9 & Tan et $a l^{14}$ & 2006 & Yes & Yes & Yes & Yes & $86.70 \%$ & 5 \\
\hline 10 & Liang et $a l^{15}$ & 2010 & Yes & Yes & Yes & Yes & $84 \%$ & 5 \\
\hline 11 & $\begin{array}{l}\text { Bueno-Gimeno } \\
\text { et a/ }{ }^{16}\end{array}$ & 2002 & Yes & Yes & Yes & Yes & NA & 4 \\
\hline 12 & Luthra et $a l^{17}$ & 2001 & Yes & Yes & Yes & Yes & $93 \%$ & 5 \\
\hline 13 & McCarty et $a l^{18}$ & 2000 & Yes & Yes & Yes & Yes & NA & 4 \\
\hline 14 & Shiroma et $a l^{19}$ & 2009 & Yes & Yes & Yes & Yes & $81.20 \%$ & 5 \\
\hline 15 & Ma et $a^{20}$ & 2007 & Yes & Yes & Yes & Yes & NA & 4 \\
\hline 16 & $\begin{array}{l}\text { West and } \\
\text { Muñoz } B^{21}\end{array}$ & 2009 & Yes & Yes & Yes & Yes & NA & 4 \\
\hline 17 & Liu et $a^{22}$ & 2001 & Yes & Yes & Yes & Yes & NA & 4 \\
\hline 18 & Gazzard et $a^{R^{3}}$ & 2002 & Yes & Yes & Yes & Yes & $96.70 \%$ & 5 \\
\hline 19 & Sherwin et $\mathrm{al}^{24}$ & 2013 & Yes & Yes & Yes & Yes & $61.50 \%$ & 5 \\
\hline 20 & Lu et af & 2007 & Yes & Yes & Yes & Yes & $84.69 \%$ & 5 \\
\hline
\end{tabular}

Figure 2 Forest plot displaying the pooled prevalence of pterygium in the population of the world.

\section{Proportion: 95\% Confidence Interval}

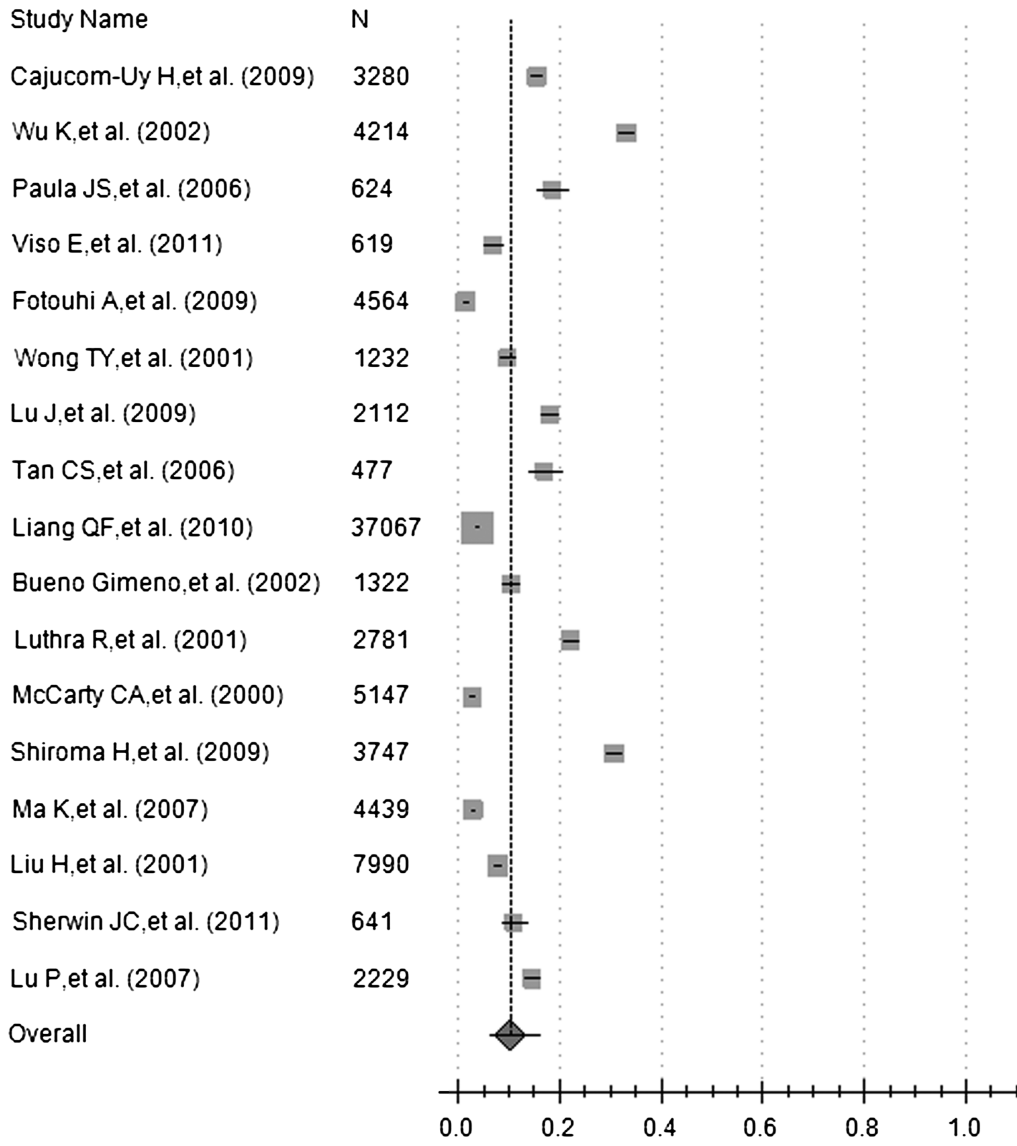

Confidence Interval

$0.155(0.143,0.168)$

$0.330(0.316,0.344)$

$0.184(0.156,0.217)$

$0.068(0.051,0.091)$

$0.014(0.011,0.018)$

$0.097(0.082,0.115)$

$0.179(0.163,0.196)$

$0.170(0.139,0.206)$

$0.038(0.036,0.040)$

$0.104(0.089,0.122)$

$0.220(0.205,0.236)$

$0.028(0.023,0.032)$

$0.308(0.293,0.323)$

$0.029(0.024,0.034)$

$0.079(0.073,0.085)$

$0.109(0.087,0.136)$

$0.145(0.131,0.160)$

$0.102(0.063,0.161)$ 
the data for the pooled prevalence. All meta-analyses were evaluated for heterogeneity using the $\chi^{2}$-based $\mathrm{I}^{2}$ test and $Q$ test. ${ }^{26} \mathrm{I}^{2}$ Test estimated the percentage of the total variance in all of the data under consideration that was related to heterogeneity. The authors suggested using 25\%, 50\% and $75 \%$ to indicate low-level, moderate-level or high-level heterogeneity. If there was moderate-level or high-level heterogeneity, a random-effects meta-analysis was performed by the DerSimonian and Laird method, except where fixed-effects models were used. Publication bias was assessed by visually inspecting a funnel plot. A p value less than 0.05 was considered statistically significant. ${ }^{27} 28$

\section{RESULTS}

The pooled prevalence rate of pterygium was $10.2 \%$ (95\% CI $6.3 \%$ to $16.1 \%$; $\mathrm{I}^{2}=49.9 \%, \mathrm{Q}=1.00$; $\mathrm{p}<0.001$ ) in the overall population (figure 2). The maximum (33\%) and minimum $(2.8 \%)$ prevalence rates of pterygium appeared in the studies by Wu $e t a l^{7}$ and McCarty et $a l^{18}$ respectively. The pooled prevalence was $13.2 \%$ (95\% CI
$4.7 \%$ to $\left.31.8 \% ; \mathrm{I}^{2}=50 \%, \mathrm{Q}=1.00 ; \mathrm{p}<0.001\right)$ for the rural population in five studies, and it was higher than the pooled prevalence of $6.3 \%$ (95\% CI $0.9 \%$ to $32.3 \%$; $\left.\mathrm{I}^{2}=49.9 \%, \mathrm{Q}=0.99 ; \mathrm{p}<0.001\right)$ for the urban population in three studies. The pooled prevalence rates for pterygium were $14.5 \%$ (95\% CI $9.1 \%$ to $22.2 \% ; \mathrm{I}^{2}=49.8 \%, \mathrm{Q}=1.00$; $\mathrm{p}<0.001)$ in men and $13.6 \%(95 \%$ CI $7.5 \%$ to $23.5 \%$; $\left.\mathrm{I}^{2}=49.9 \%, \mathrm{Q}=1.00 ; \mathrm{p}<0.001\right)$ in women, respectively. The pooled prevalence rate for participants with unilateral cases of pterygium was higher than that for those with bilateral pterygium ( $8 \%$ vs $6.2 \%)$. After removing other countries, we found that the pooled prevalence of pterygium in six studies from China was $9.9 \%$ (95\% CI $4 \%$ to $\left.22.7 \% ; \mathrm{I}^{2}=50 \%, \mathrm{Q}=1.00 ; \mathrm{p}<0.001\right)$, which was similar to the overall pooled prevalence of pterygium in the world.

There was a significant trend of greater prevalence for pterygium at older ages (40-49 vs 50-59 vs 60-69 years, $11 \%$ vs $15.6 \%$ vs $20.1 \%$ ), and the trends were generally similar between the 60-69 and over 70 years age groups (20.1\% vs $20.2 \%)$. This report presented trends in the pooled prevalence of pterygium varied with increasing geographical latitude. The pooled prevalence of
Figure 3 Forest plot displaying the pooled ORs and trends of pterygium: (A) OR for male gender; (B) OR for outdoor activity; (C) trend for age groups and prevalence of pterygium; and (D) trend for geographical latitude and prevalence of pterygium.

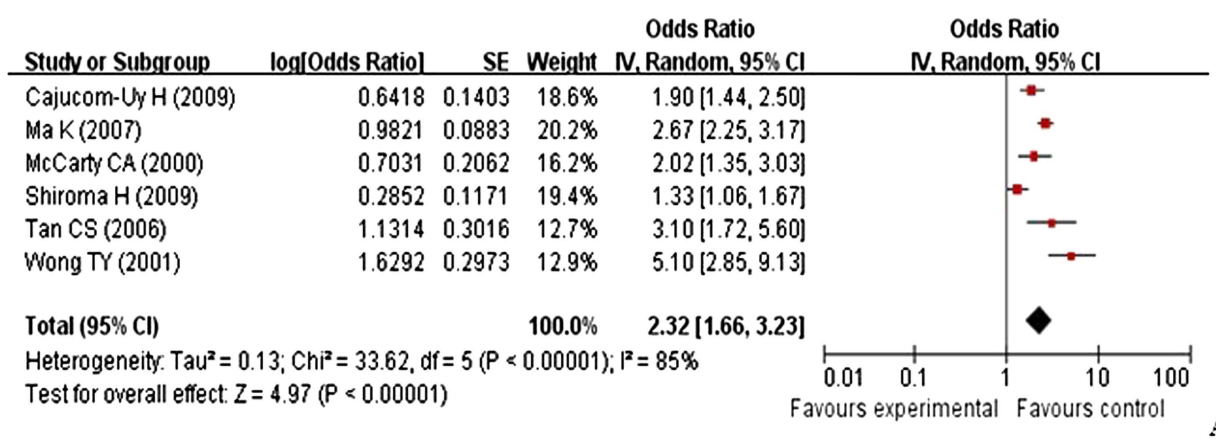

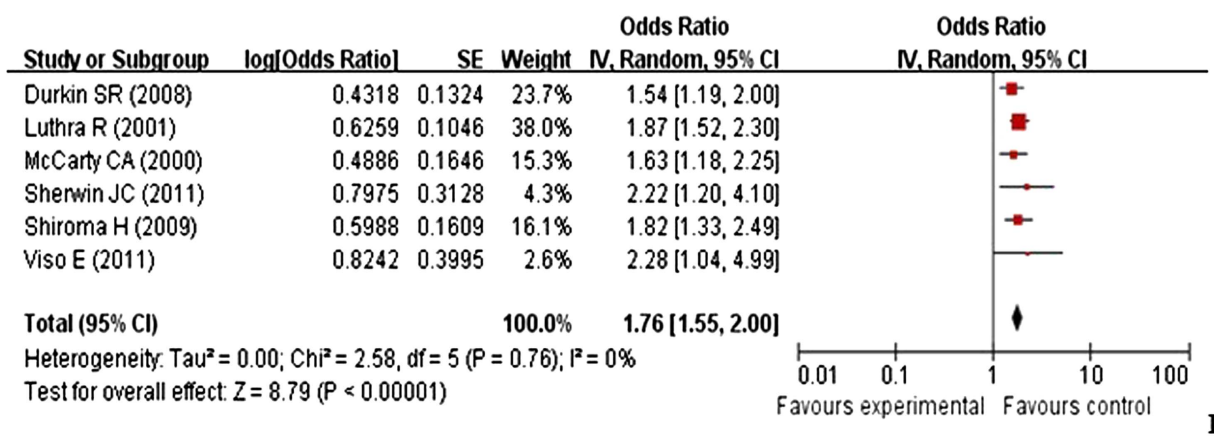
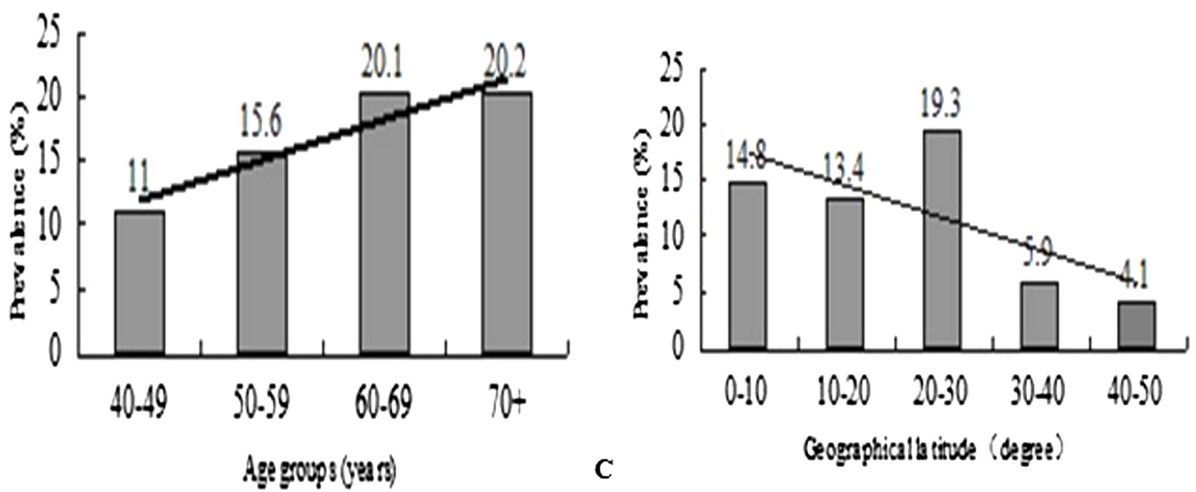
pterygium $\left(19.3 \%\right.$, $95 \%$ CI $12.4 \%$ to $28.9 \%$; $\mathrm{I}^{2}=49.8 \%$, $\mathrm{Q}=0.99 ; \mathrm{p}<0.001)$ whose stations were located in the latitude ranges of $20-30^{\circ}$ was higher than for those in any other areas (figure 3 ). In addition, the prevalence rates comparing men and women, unilateral versus bilateral, Chinese articles, age and latitude are shown in table 3.

Six studies investigated the association between male gender and pterygium. The pooled OR was $2.32(95 \%$ CI 1.66 to 3.23 ; $\left.\mathrm{I}^{2}=85 \%, \mathrm{p}<0.001\right)$ for the male gender. There were six articles which provided information on the relationship between outdoor sun exposure and pterygium, and the OR was 1.76 (95\% CI 1.55 to 2; $\mathrm{I}^{2}=0 \%, \mathrm{p}=0.76$ ) for outdoor sun exposure (figure 3 ).

There were other risk factors for pterygium by logistic regression in the reviewed studies, but the pooled ORs could not be calculated because little information in estimating. The risk factors are shown in table 4 .

All comparisons passed the test of heterogeneity, as previously defined random-effects models were used for meta-analyses. The funnel plot of the overall pooled prevalence of pterygium is shown in figure 4. The funnel plot had the expected funnel shape. There was no significant publication bias in this meta-analysis.

\section{DISCUSSION}

The prevalence of pterygium varied widely across studies. A simple meta-analysis to combine the findings of studies would be informative. To our knowledge, this is the first meta-analysis of prevalence rate and risk factors for

\begin{tabular}{|c|c|c|}
\hline Subgroups & $\begin{array}{l}\text { The pooled } \\
\text { prevalence rates } \\
\text { of pterygium (\%) }\end{array}$ & p Value \\
\hline \multicolumn{3}{|l|}{ Gender } \\
\hline Males & 14.5 & 0.03 \\
\hline Females & 13.6 & \\
\hline \multicolumn{3}{|l|}{ Unilateral or bilateral } \\
\hline Unilateral pterygium cases & 8 & $<0.01$ \\
\hline Bilateral pterygium cases & 6.2 & \\
\hline \multicolumn{3}{|l|}{ Area } \\
\hline Pterygium in China & 9.9 & 0.06 \\
\hline Pterygium in the world & 10.2 & \\
\hline \multicolumn{3}{|l|}{ Age group, years } \\
\hline $40-49$ & 11 & $<0.01$ \\
\hline $50-59$ & 15.6 & \\
\hline $60-69$ & 20.1 & \\
\hline \multicolumn{3}{|l|}{ Old age group, years } \\
\hline $60-69$ & 20.1 & 0.12 \\
\hline $70-79$ & 20.2 & \\
\hline \multicolumn{3}{|l|}{ Different parallel latitude } \\
\hline $0-10$ & 14.8 & 0.01 \\
\hline $10-20$ & 13.4 & \\
\hline $20-30$ & 19.3 & \\
\hline $30-40$ & 5.9 & \\
\hline $40-50$ & 4.1 & \\
\hline
\end{tabular}

pterygium in the world. In this meta-analysis, a total of 20 studies with 900545 samples were included. We showed that the pooled prevalence rate of pterygium was $10.2 \%$ (95\% CI $6.3 \%$ to $16.1 \%)$ in the general population. The eligible studies covered 12 countries. There was a similarity in prevalence of pterygium between China and the world, which might have resulted in the region of China being located mostly in the low-to-high latitude regions, but the prevalence of pterygium $(33 \%)$ in the Doumen County of China was highest in this systematic review. ${ }^{7}$ This indicates a strong requirement for prevention and treatment strategies to control pterygium disease.

Researches on whether gender is related to pterygium have been uncertain. ${ }^{2}{ }^{6-24}$ Many previous studies suggested that the prevalence of pterygium was higher in the male gender than in the female gender, ${ }^{6} 14151924$ which is consistent with the results of this meta-analysis (men vs women, $14.5 \%$ vs $13.6 \%$ ). The pooled OR was 2.32 (95\% CI 1.66 to 3.23) for the male gender. Previous studies by $\mathrm{Lu} e t a l^{2}$ reported that women were at higher risk than men (OR 1.6, 95\% CI 1.2 to 2) after logistic regression, which involved in the lifestyle for Tibetan women who had much rural and outdoor work.

Results by this meta-analysis suggested that the prevalence of pterygium in the rural population was higher than that in the urban population, because rural people were often involved in much outdoor work. We found a significant positive trend between increasing age and the prevalence of pterygium, so the importance of organising healthcare for the elderly to prevent pterygium cannot be underestimated.

Epidemiological associations have been suggested between outdoor activity and the prevalence of pterygium, ${ }^{9} 11$ 17-1924 and the pooled OR of outdoor activity for pterygium was 1.76 (95\% CI 1.55 to 2). Adding even more outdoor activity makes it a great time to get more exposure to sunlight. A strong positive correlation between climatic UV radiation and the prevalence of pterygium ${ }^{29}$ was found. It is also known that the low geographical latitude regions are exposed to higher sunlight. There was a trend between higher geographical latitude and lower prevalence of pterygium beside areas located in the latitude range of $20-30^{\circ}$. We are not aware of the reason why the prevalence of pterygium was a little higher in the latitude range of $20-30^{\circ}$ than that in low latitude regions.

However, the findings had substantial heterogeneity $(p<0.001)$, possibly due to the confounding effects of differences in age, distribution of participants and so on.

Although we have estimated the pooled prevalence of pterygium in the world, which is very important for preventative public health, there are some limitations in this meta-analysis. First, we only included studies written in English or Chinese and published from January 2000 to May 2013, so the pooled prevalence of pterygium in specific regions and periods is explained by the results. In addition, further evidence might have emerged subsequent to our original search, and the results of the 
Table 4 Risk factors of the population-based studies by logistic regression for prevalence of pterygium

\begin{tabular}{|c|c|c|c|c|}
\hline First author & Publication year & Risk factors & OR & $95 \% \mathrm{Cl}$ \\
\hline \multirow[t]{3}{*}{ Cajucom-Uy et af } & 2010 & Age & 1.3 & 1.1 to 1.4 \\
\hline & & Male gender & 1.9 & 1.5 to 2.6 \\
\hline & & High systolic blood pressure & 1.6 & 1.2 to 2.1 \\
\hline \multirow[t]{2}{*}{ Viso et aP } & 2011 & Outer activity & 2.28 & 1.04 to 4.98 \\
\hline & & fluorescein staining & 2.64 & 1.08 to 6.46 \\
\hline Fotouhi et al ${ }^{10}$ & 2009 & Age $(60+)$ & 73.6 & 17.1 to 316.1 \\
\hline Durkin et al ${ }^{11}$ & 2008 & Primarily outdoor & 1.54 & 1.19 to 2 \\
\hline \multirow[t]{4}{*}{ Wong et $a l^{12}$} & 2001 & Male gender & 5.1 & 2.9 to 9.3 \\
\hline & & Age (50-59) & 3.7 & 1.5 to 9.4 \\
\hline & & Age (60-69) & 6.3 & 2.6 to 15.1 \\
\hline & & Age (70-81) & 7.8 & 3.2 to 18.8 \\
\hline \multirow[t]{10}{*}{ Lu et $a l^{13}$} & 2009 & Age (70-79) & 2 & 1.4 to 2.8 \\
\hline & & Alcohol intake & 1.5 & 1 to 2 \\
\hline & & Education (<3 years) & 2.1 & 1.4 to 3.2 \\
\hline & & Dry eye symptoms & 1.9 & 1.5 to 2.5 \\
\hline & & Poor family situation & 1.3 & 1 to 1.6 \\
\hline & & Schirmer's test $(\leq 5 \mathrm{~mm})$ & 2.4 & 1.9 to 3.1 \\
\hline & & Tear break-up time ( $\leq 10 \mathrm{~s})$ & 2.3 & 1.8 to 2.9 \\
\hline & & Seldom use of sunglasses & 1.5 & 1.2 to 1.9 \\
\hline & & Seldom use of hat & 1.3 & 1.1 to 1.7 \\
\hline & & Cataract & 1.5 & 1.1 to 1.9 \\
\hline Tan et $a l^{14}$ & 2006 & Male gender & 3.1 & 1.72 to 5.61 \\
\hline \multirow[t]{6}{*}{ Luthra et al ${ }^{17}$} & 2001 & Age & 1.01 & 1 to 1.02 \\
\hline & & Education (<12 years) & 1.43 & 1.01 to 2.03 \\
\hline & & Outer activity & 1.87 & 1.52 to 2.29 \\
\hline & & Darker skin complexion & 0.66 & 0.52 to 0.83 \\
\hline & & Using sunglasses outdoor & 0.18 & 0.06 to 0.59 \\
\hline & & Use of prescription glasses & 0.75 & 0.6 to 0.93 \\
\hline \multirow[t]{4}{*}{ McCarty et al ${ }^{18}$} & 2000 & Age group (10 year) & 1.23 & 1.06 to 1.44 \\
\hline & & Male gender & 2.02 & 1.35 to 3.03 \\
\hline & & Rural residence & 5.28 & 3.56 to 7.84 \\
\hline & & Lifetime ocular sun exposure & 1.63 & 1.18 to 2.25 \\
\hline \multirow[t]{5}{*}{ Shiroma et al ${ }^{19}$} & 2009 & Male gender & 1.33 & 1.03 to 1.63 \\
\hline & & Age (years) & 1.02 & 1.01 to 1.03 \\
\hline & & Refractive error & 1.08 & 1.03 to 1.13 \\
\hline & & Experience of outdoor jobs & 1.82 & 1.33 to 2.5 \\
\hline & & Intraocular pressure & 0.96 & 0.94 to 0.98 \\
\hline Ma et $a{ }^{R 0}$ & 2007 & Male gender & 2.67 & 2.25 to 3.18 \\
\hline \multirow[t]{4}{*}{ West and Muñoz $B^{21}$} & 2009 & Education (<6 years) & 2.81 & 2.18 to 3.62 \\
\hline & & Income $<20000$ & 1.24 & 1.03 to 1.51 \\
\hline & & Smoking & 0.75 & 0.59 to 0.94 \\
\hline & & Bilateral cataract surgery & 0.54 & 0.35 to 0.83 \\
\hline \multirow[t]{2}{*}{ Gazzard et $a^{23}$} & 2002 & Age (51 and above) & 7.31 & 2.36 to 22.7 \\
\hline & & Smoking & 0.46 & 0.24 to 0.9 \\
\hline \multirow[t]{3}{*}{ Sherwin et af4 } & 2013 & Outdoor $>3 / 4$ day & 2.22 & 1.2 to 4.09 \\
\hline & & Ultraviolet autofluorescence (per $10 \mathrm{~mm}$ ) & 1.16 & 1.05 to 1.28 \\
\hline & & Skin type (tans) & 2.17 & 1.2 to 3.92 \\
\hline \multirow[t]{9}{*}{ Lu et $a$ R } & 2007 & Age $(70-79)$ & 2 & 1.4 to 2.8 \\
\hline & & Female gender & 1.6 & 1.2 to 2 \\
\hline & & Education (<3 years) & 1.6 & 1.1 to 2.4 \\
\hline & & Dry eye symptoms & 1.3 & 1 to 1.7 \\
\hline & & Use of sunglasses/stone glasses & 0.3 & 0.1 to 0.8 \\
\hline & & Use of hats & 0.3 & 0.2 to 0.5 \\
\hline & & Seldom use of sunglasses/stone glasses & 4.6 & 1.9 to 11.3 \\
\hline & & Seldom use of hats & 3.6 & 2.4 to 5.4 \\
\hline & & Low socioeconomic status & 1.9 & 1.5 to 2.4 \\
\hline
\end{tabular}


Funnel Plot

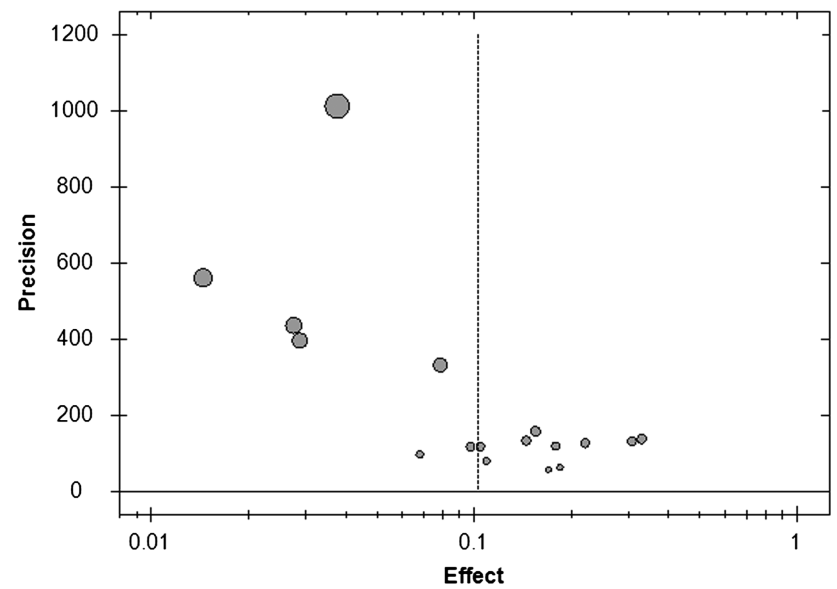

Figure 4 Funnel plot of studies conducted on the prevalence of pterygium in the world.

meta-analysis must be updated in time. Second, as we cannot have access to unpublished results, a publication bias cannot be excluded. Third, a pooled analysis of some other risk factors was not produced due to insufficient data.

Described as an 'ophthalmic enigma', ${ }^{30}$ the prevalence of pterygium was $10.2 \%$ in the world. Healthcare providers should be aware of preventing pterygium, especially in the elderly and people in low latitude regions.

\section{Author affiliations}

${ }^{1}$ Department of Ophthalmology, The First Affiliated Hospital, China Medical University, Shenyang, China

${ }^{2}$ Department of Epidemiology, School of Public Health, China Medical University, Shenyang, China

${ }^{3}$ Department of Mathematics, College of Basic Medical Sciences, China

Medical University, Shenyang, China

Acknowledgements This study was supported by the Liaoning Diabetic Eye Center, the Liaoning Provincial Key Laboratory of Endocrine Diseases and the Endocrine Institute of China Medical University. The authors would like to thank Jingpu Shi, PhD, Professor of the Department of Clinical Epidemiology and Evidence Medicine in the First Affiliated Hospital of China Medical University. They also thank Dr Sharon Forsyth, Director of Biomedical Editing International for English editing.

Contributors $\mathrm{LL}$ and $\mathrm{DH}$ conceived and designed the experiments. $\mathrm{LL}, \mathrm{ZY}$ and JW performed the experiments. DH, LL, JG and JW analysed the data. $L L, J G$ and $\mathrm{DH}$ wrote the article.

Funding This research received no specific grant from any funding agency in the public, commercial or not-for-profit sectors.

Competing interests None.

Provenance and peer review Not commissioned; externally peer reviewed.

Data sharing statement No additional data are available.

Open Access This is an Open Access article distributed in accordance with the Creative Commons Attribution Non Commercial (CC BY-NC 3.0) license, which permits others to distribute, remix, adapt, build upon this work noncommercially, and license their derivative works on different terms, provided the original work is properly cited and the use is non-commercial. See: http:// creativecommons.org/licenses/by-nc/3.0/

\section{REFERENCES}

1. Li M, Zhu M, Yu Y, et al. Comparison of conjunctival autograft transplantation and amniotic membrane transplantation for pterygium: a meta-analysis. Graefes Arch Clin Exp Ophthalmol 2012;250:375-81.

2. Lu $\mathrm{P}$, Chen $\mathrm{X}$, Kang $\mathrm{Y}$, et al. Pterygium in Tibetans: a populationbased study in China. Clin Experiment Ophthalmol 2007;35:828-33.

3. Al-Bdour M, Al-Latayfeh M. Risk factors for pterygium in an adult Jordanian population. Acta Ophthalmol Scand 2004;82:64-7.

4. Threlfall TJ, English DR. Sun exposure and pterygium of the eye: a dose-response curve. Am J Ophthalmol 1999;128:280-7.

5. Moher D, Liberati A, Tetzlaff J, et al. Preferred reporting items for systematic reviews and meta-analyses: the PRISMA statement. PLOS Med 2009;6:e1000097.

6. Cajucom-Uy H, Tong L, Wong TY, et al. The prevalence of and risk factors for pterygium in an urban Malay population: the Singapore Malay Eye Study (SiMES). Br J Ophthalmol 2010;94:977-81.

7. Wu K, He M, Xu J, et al. Pterygium in aged population in Doumen County, China. Yan Ke Xue Bao 2002;18:181-4.

8. Paula JS, Thorn F, Cruz AA. Prevalence of pterygium and cataract in indigenous populations of the Brazilian Amazon rain forest. Eye (Lond) 2006;20:533-6.

9. Viso E, Gude F, Rodríguez-Ares MT. Prevalence of pinguecula and pterygium in a general population in Spain. Eye (Lond) 2011;25:350-7.

10. Fotouhi A, Hashemi H, Khabazkhoob M, et al. Prevalence and risk factors of pterygium and pinguecula: the Tehran Eye Study. Eye (Lond) 2009;23:1125-9.

11. Durkin SR, Abhary S, Newland HS, et al. The prevalence, severity and risk factors for pterygium in central Myanmar: the Meiktila Eye Study. Br J Ophthalmol 2008;92:25-9.

12. Wong TY, Foster PJ, Johnson GJ, et al. The prevalence and risk factors for pterygium in an adult Chinese population in Singapore: the Tanjong Pagar survey. Am J Ophthalmol 2001;131:176-83.

13. Lu J, Wang Z, Lu P, et al. Pterygium in an aged Mongolian population: a population-based study in China. Eye (Lond) 2009;23:421-7.

14. Tan CS, Lim TH, Koh WP, et al. Epidemiology of pterygium on a tropical island in the Riau Archipelago. Eye (Lond) 2006;20:908-12.

15. Liang QF, Xu L, Jin XY, et al. Epidemiology of pterygium in aged rural population of Beijing, China. Chin Med J (Engl) 2010;123:1699-701.

16. Bueno-Gimeno I, Montés-Micó R, España-Gregori E, et al. Epidemiologic study of pterygium in a Saharan population. Ann Ophthalmol 2002;34:43-6.

17. Luthra R, Nemesure BB, Wu SY, et al. Frequency and risk factors for pterygium in the Barbados Eye Study. Arch Ophthalmol 2001;119:1827-32.

18. McCarty CA, Fu CL, Taylor HR. Epidemiology of pterygium in Victoria, Australia. Br J Ophthalmol 2000;84:289-92.

19. Shiroma H, Higa A, Sawaguchi S, et al. Prevalence and risk factors of pterygium in a southwestern island of Japan: the Kumejima Study. Am J Ophthalmol 2009;148:766-771.e1.

20. Ma K, Xu L, Jie $\mathrm{Y}$, et al. Prevalence of and factors associated with pterygium in adult Chinese: the Beijing Eye Study. Cornea 2007:26:1184-6.

21. West $S$, Muñoz B. Prevalence of pterygium in Latinos: Proyecto VER. Br J Ophthalmol 2009;93:1287-90.

22. Liu $\mathrm{H}$, Yang J, Zhong L. Prevalence survey on pterygium in two counties of Hainan Province. Zhonghua Yan Ke Za Zhi 2001;37:21-3.

23. Gazzard G, Saw SM, Farook M, et al. Pterygium in Indonesia: prevalence, severity and risk factors. $\mathrm{Br} J$ Ophthalmol 2002;86:1341-6.

24. Sherwin JC, Hewitt AW, Kearns LS, et al. The association between pterygium and conjunctival ultraviolet autofluorescence: the Norfolk Island Eye Study. Acta Ophthalmol 2013;91:363-70.

25. Stroup DF, Berlin JA, Morton SC, et al. Meta-analysis of observational studies in epidemiology: a proposal for reporting. Meta-analysis Of Observational Studies in Epidemiology (MOOSE) group. JAMA 2000;I283:2008-12.

26. Higgins JP, Thompson SG, Deeks JJ, et al. Measuring inconsistency in meta-analyses. BMJ 2003;327:557-60.

27. Mantel J, Haenszel W. Statistical aspects of the analysis of data from retrospective studies of disease. J Natl Cancer Inst 1959;22:719-48.

28. Der Simonian R, Laird N. Meta-analysis in clinical trials. Control Clin Trials 1986;7:177-88.

29. Saw SM, Tan D. Pterygium: prevalence, demography and risk factors. Ophthalmic Epidemiol 1999;6:219-28.

30. Coster D. Pterygium - an ophthalmic enigma. Br J Ophthalmol 1995;79:304-5. 
Correction: Geographical prevalence and risk factors for pterygium: a systematic review and meta-analysis

Liu L, Wu J, Geng J, et al. Geographical prevalence and risk factors for pterygium: a systematic review and meta-analysis. BMJ Open 2013;3:e003787. doi: 10.1136/ bmjopen-2013-003787

In the abstract, the sentence:

"We found a trend that the higher pooled prevalence of pterygium was associated with increasing geographical latitude and age in the world."

should read:

"We found a trend that the higher pooled prevalence of pterygium was associated with decreasing geographical latitude and age in the world."

Open Access This is an Open Access article distributed in accordance with the Creative Commons Attribution Non Commercial (CC BY-NC 4.0) license, which permits others to distribute, remix, adapt, build upon this work non-commercially, and license their derivative works on different terms, provided the original work is properly cited and the use is non-commercial. See:http://creativecommons.org/licenses/by-nc/4.0/

(c) Article author(s) (or their employer(s) unless otherwise stated in the text of the article) 2017. All rights reserved. No commercial use is permitted unless otherwise expressly granted.

BMJ Open 2017;7:e003787corr1. doi:10.1136/bmjopen-2013-003787corr1

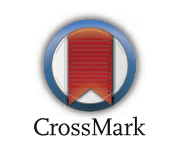

